\title{
CutBank
}

Volume 1

Issue 39 CutBank 39

Article 30

Winter 1993

\section{Interview with Galway Kinnell}

Bette Tomlinson

Galway Kinnell

Follow this and additional works at: https://scholarworks.umt.edu/cutbank

Part of the Creative Writing Commons

Let us know how access to this document benefits you.

\section{Recommended Citation}

Tomlinson, Bette and Kinnell, Galway (1993) "Interview with Galway Kinnell," CutBank: Vol. 1 : Iss. 39 , Article 30.

Available at: https://scholarworks.umt.edu/cutbank/vol1/iss39/30

This Prose is brought to you for free and open access by ScholarWorks at University of Montana. It has been accepted for inclusion in CutBank by an authorized editor of ScholarWorks at University of Montana. For more information, please contact scholarworks@mso.umt.edu. 


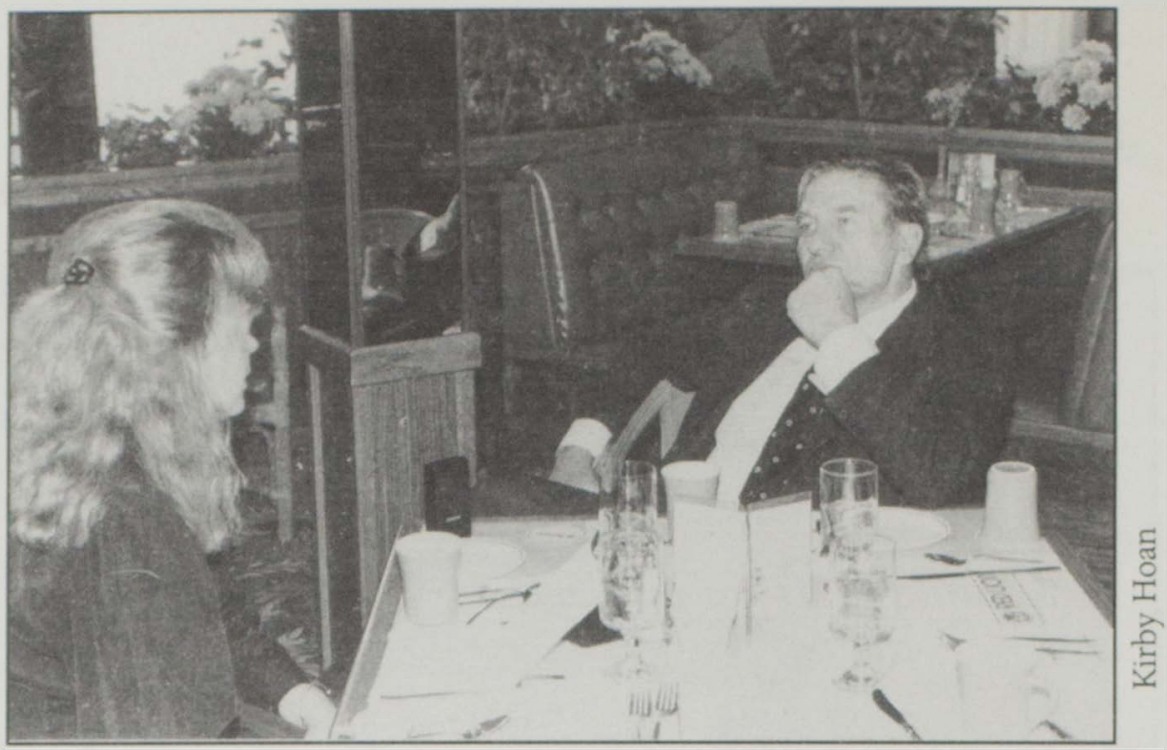

INTERVIEW WITH GALWAY KINNELL

\author{
conducted by Bette Tomlinson \\ Missoula, Montana \\ April, 1992
}

BT: I remember hearing you deliver the welcoming address at the Squaw Valley Community of Writers in 1987. You said to all of us then: "While you are here, I want you to aspire to greatness." What do you mean by greatness?

GK: Something that's alive and has truth in it and gets more of what and who you are out onto the page.

BT: How do you view the language poets' experimentation with what and who they are?

GK: I think that it's interesting to them. It's not interesting to me. I don't write poetry of that kind, nor read much theoretical decon- 
structionist criticism. I think, in principle, that it's good that poetry continue to have offshoots and developments. But I expect that poetry will always have a core and that core will be that in which a person simply tells what it is for the author to be here.

BT: Doesn't the telling of that core experience always have some political orientation?

GK: I want to try to understand experience a little, not just present it. See into it and perhaps illuminate it a bit. I suppose that that could be seen as teaching, but I see it more as discovering. The writer is in a different position than the reader.

BT: You have said that Patrick Kavanaugh and John Clare are recently of interest to you. How do they influence you?

GK: They don't belong to the golden tradition of poetry in English, which is a kind of desire to transcend our mortal life, in which things are turned into symbols quickly and become something else. Clare and Kavanaugh are peasant poets, one English and one Irish, and describe experience more or less the way they see it. Kavanaugh writes about potatoes and his little triangular farm, about his father and his mother and about drinking too much, whereas Yeats talks about the larger issues of Irish politics and the symbolic life. Those things are wonderful to write about, but Yeats leaves out ordinary, rough, plain, unmediated reality. Kavanaugh is a nice corrective Kavanaugh is much beloved in Ireland, probably more so than Yeats. For the ordinary person who reads Irish poetry, Yeats is a little bit elitist, from their point of view. I don't think so, but Kavanaugh is like one of them and talks about the life that they know. Clare, really-the same situ- 
ation. If you compare his poems about nightingales to those of Keats, you see the tremendous difference. Keats' nightingale hardly appears in Keats' "Ode to a Nightingale." There are a couple of lines about the voice, but Keats goes right into the symbolic world - the world of art. When Clare writes about nightingales, he creeps through the woods and parts the leaves and looks at them in their nests. He describes them as real creatures of our earth. Then he describes their singing. There's one poem which has ten lines which consist entirely of phonetic transcriptions of the various, different songs of the nightingale. It's amazing. He really knew the nightingale-he was its cousin. I think of Keats as the greatest of all lyric poets in the language. But sometimes I think that I like Clare just as well. Clare was a little cracked and spent much of his life in an asylum. That crack let in some light that a whole brain doesn't let in. So he understood some things in an odd, unusual way.

BT: So, the graceful simplicity of your lyrical style derives from a desire for the real things of the real earth.

GK: Yes, it's a turn I've taken toward the actual.

BT: What are you working on now?

GK: I'm writing poems about childhood, about my parents and about what I may have been like as a child. I'm writing about political issues and social mood. I'm writing some love poems, poems about sexual love and poems about despised things - trying to restore to them their dignity. One about flies-house flies - and one about shit. 
BT: You have written poems that tell a story-but not in the way which is recently popularized as the neo-narrative.

GK: I think just to tell a story-it can be done in poetry, and certainly has been done, but in my opinion, prose developed as a more supple and adequate way of telling a story than poetry and in a way relieves poetry of the duty to tell these long stories that produced The Iliad and The Odyssey and The Aeneid, and so on, but at the same time produced "Hiawatha," and very dull nineteenth-century narratives. I really like poetry in which there is a deep and intense personal engagement. That's my preference based, like most poets, on my practice. It is true that poet critics' criticism is often a reflection of a struggle that they are going through regarding their own enterprises. So it's quite mistaken of them to turn this struggle with their own work to a universal principle.

BT: You did begin as a formalist poet and evolved, like many of your generation, away from that style. What do you think about the recent return, by many young poets, to the strictures of formal verse?

GK: You can see the point of that position. When we turned away from formal poetry to free verse it seemed that poetry had become too stuffy, too boxed-in, too literary, too full of the whole baggage of poetic diction and had become incapable of talking about the ordinary things in an ordinary way. So it seemed a very healthy thing to turn to free verse. However, it's no doubt true that there's a lot of free verse that's just prose cut up into segments. A poem must have form to be shapely, to give the sense of lastingness. 
That's probably a good motivation for people to turn back to rhythm and meter. I would never do so myself. I would try to make my own free verse more solid. Rather than think that formlessness was intrinsic to free verse, I would try to make a free verse that doesn't arouse the anxiety that poetry is in a headlong slide to prose.

BT: How would you characterize what is alternately labeled a renaissance of poetry in this country and an irrelevant form?

GK: There is a large audience for poetry in this country, compared to what there was when I started writing. It is a very small percentage however, in comparison to the nineteenth-century, when Longfellow was a bestseller. But the audience for poetry now is a much more knowledgeable and interesting audience. The nineteenth-century audience wanted sentimental, wishful thinking and neither Dickinson nor Whitman could make a dent in that world. Our two greatest poets were completely ignored. It's no loss to lose that audience, really, because it allows another kind of audience to develop-which has happened. Probably half of today's audience is made up of people who write poetry themselves and I think that's good. I think this ferment, this thick and overlapping network of people who write throughout our country is a very healthy one. I don't think that there is any other country in the world that has poetry readings on the scale and of the frequency that we have. On any given night in the United States, it is almost certain that there are more people listening to poetry at readings all over the country than are listening in the rest of the world, combined. Our society is so filled with things that claim our attention, like sports, or television programs, or political de- 
bates, or any of the things that fill people's evenings-really, the last thing that people do, because it's the hardest, is to sit down and read poetry. When you go to a basketball game, you don't give anything of yourself-you get. When you turn on the television set, you sit back on the couch and you just receive. With poetry, you not only have to say the words, you have to put your life and your feelings into those words and to understand them. It's no easy thing to read a poem. It's no wonder that poetry is a minority art and will always be-that's how it has always been. We're at an exciting time- the whole of poetry has changed in the last generation. All sorts of things that we thought were taboo, that were thought unworthy of poetry, that were thought too shameful to be written about, have now become the subjects of poetry. In a sense, you could say that poetry is just in its infancy, because we have just begun to realize that there are whole worlds out there that have never been articulated in poems. It's a very exciting time. 